\title{
The trans-Tasman Cable, the Australasian Bridgehead and Imperial History
}

\author{
We are running a race with Time; \\ we outstrip the sun, with the round world for \\ the race-course. ${ }^{1}$
}

The implementation of an imperial telegraph network over the course of the late nineteenth century caused a considerable amount of ink to be spilled, in praise, in fear and in confusion. By 1876, with the completion of the trans-Tasman cable between Australia and New Zealand, the British government could communicate with all of its major colonies by electric telegraph. As long as the lines remained intact (this was by no means a certainty), a message could be conveyed from London to Wellington, New Zealand, via the "thunderbolts of Jove". ${ }^{2}$ The rapid contraction of time and space that this entailed was much commented upon by contemporaries, who marvelled at the reduction in communication time between England and her antipodes from 3-4 months to a matter of hours. As the most distant colony in the empire, New Zealanders took up the new technology with alacrity: by 1904 New Zealand telegraph traffic ran at twice the rate of any other country in the world, and 5 times the rate in the United States. ${ }^{3}$ Although the bulk of these messages merely circuited throughout New Zealand and wider Australasia, it is quite clear that the telegraph was quickly identified as a useful tool of colonisation and nation building.

Of course, the growth of the nineteenth century telegraph network captivated people worldwide. It came to symbolise the new power over nature represented by technological modernity. One commentator referred to the wires as "the nerves of the earth"4 and early biologists like Emil DuBois-Reymond (1818-1896) used the metaphor of telegraph systems to formulate his theory of the human nervous system. ${ }^{5}$ 
Electromagnetic telegraphy was closely related to more general advances in science and engineering associated with not only DuBois-Reymond and other early scientists like Alessandro Volta (1745-1827), Han Oersted (1777-1851), and George Simon Ohm (1787-1854), but the magical wires that transmitted messages across land and under the oceans had immediate implications for empire builders and strategists alike. ${ }^{6}$ Electric telegraphy was viewed by its various inventors and promoters as a 'tool of empire', capable of uniting the empire at the very point at which it appeared to be losing cohesion. In retrospect, it is natural enough to suggest that that the telegraph, along with the steamship and railways, was one of the key catalysts behind the "imperialist euphoria [of] the last third of the nineteenth century". ${ }^{7}$

This is the claim of a number of recent (and not so recent) histories of technology in the British Empire, which all position the imperial telegraph network as a key agent of social, economic and cultural change across both individual colonies and the empire as a whole, suggesting that it was one important element in a complex matrix of communication, representation and material progress which acted to not only bind the empire in time, but in purpose and belief. ${ }^{8}$ While undoubtedly correct at the macro level (the success of the cable network can be determined quantitatively in terms of commerce and qualitatively at the level of culture and politics) none of these books has within its scope an extended examination of one area of empire, one colony which could be used as a case study to explicate the more complex and contradictory impacts of the telegraph. While all of them demonstrate an awareness of the issues surrounding the history of technology - and in particular the problem of technological determinism and resultant tendencies towards Whiggishness - their macro, imperial viewpoint tends to compromise their best intentions: the telegraph network expands, the steamships and railways are developed, and the empire is enhanced. This essay 
aims to complement the approach of these studies with a micro-study of the impact of the imperial telegraph's arrival in New Zealand in 1876. As the most distant of all the British colonies (12,000 miles from London and 1200 miles from its nearest neighbour, Australia) New Zealand presents an intriguing study.

A second aim of this paper is to attempt an integration of the history of technology with what Robert Kubicek has recently termed "conventional"9 studies of empire. Although generally in praise of Marsden and Smith's book, Kubicek quite correctly points out that if the history of technology is going to offer any really tangible new perspectives on imperial history, it needs to engage with the dominant models behind the expansion, development, and ultimate dissolution of that empire. Given the multiplication of theories about empire, from studies into the 'British world' ${ }^{10}$ the evergreen Gallagher and Robinson, ${ }^{11}$ their critique by Cain and Hopkins, ${ }^{12}$ a number of studies into relationships between centre and periphery ${ }^{13}$ (reminiscent of the pioneering work by Edward Shills in America ${ }^{14}$ ), and Bernard Porter's overt comparisons between Britain's nineteenth century empire and America's (technologically enabled, it should be noted) twenty-first century one, it seems a useful project. ${ }^{15}$

Rather than provide another critique of these theories - as has been done elsewhere $^{16}$ - this paper proposes to remind readers of a solid model of empire that is infrequently cited, but of real use when analysing specific local examples of imperial expansion and consolidation. John Darwin's notion of 'imperial bridgeheads', originally published in The English Historical Review in $1997^{17}$, proposes that descriptions of British imperial expansion should acknowledge the "pluralism of British society"; the "diversity of British interests at work in the periphery"; and pay 
"careful attention to the international constraints which shaped mid- as well as late Victorian expansion":

As Gallagher and Robinson rightly insisted, it was the energy of private British interests - settler, commercial, missionary amongst others - which supplied much of the dynamic behind Victorian expansion (617).

Darwin's imperial bridgeheads represent a mixture of "commercial, industrial, missionary, scientific, settler, naval and military interests" alongside "a variety of ideological and religious messages" which acted to determine the nature of British involvement at the political, cultural and discursive level (628). This writer would add colonial (and to a lesser extent imperial) government to the mix as well, but Darwin's well-made point is that specific "bridgehead[s]" (629) were composed of different factors, "which in combination contributed to the either formal or informal nature of the relationship that evolved" (629). Darwin's solution to the question of imperial expansion proposes a closely defined model of imperial expansion, predicated on these various bridgeheads functioning as the "hinge or interface between the metropole and a local periphery". ${ }^{18}$ His model is nicely evocative of the chaos that attended British imperial advances worldwide, and works especially well for scholars attempting to understand the web of relationships that existed across the Australasian colonies during the nineteenth century. Darwin provides a complex, yet ultimately satisfying, picture of British territorial expansion that complements prior arguments and allows for the exploration of imperial history in a variety of different contexts.

The extension of the imperial telegraph system to New Zealand during the 1870s presents a good example of Darwin's bridgehead in action. The project involved a great amount of commercial and private backing, but also involved both the New Zealand and imperial governments; it functioned in a cultural and perhaps also symbolic sense as an indicator of the colony's growing technological maturity 
and (importantly) a connection to the imperial centre; and it also involved differing degrees of scientific, settler, naval, and military interests. When the cable was finally laid in 1876, completing the thousands of miles of imperial cable connections snaking towards the metropole, the trans-Tasman cable symbolised the ultimate solidification of an imperial bridgehead, focussed on Australasia (rather than merely New Zealand) and predicated upon a broad front of commercial, strategic, social and cultural phenomena.

New Zealand scholars will not be surprised at the assertion of an extraregional bridgehead in relation to late-colonial New Zealand. Australian and New Zealand scholars have long noted that the country functioned as part of the Australian frontier for much of the nineteenth century ${ }^{19}$, and the topic has recently come in for detailed examination once again. ${ }^{20}$ Contrary to James Belich's assertions that the country's history is best understood in terms of an economically determined and culturally expressed 'progress industry'21 aligned towards Britain for the vast majority of its history, it seems clear to many scholars that the initial colonisation - as well as the subsequent development of national identity - developed within a regional sphere composed of religious, commercial, agricultural, political, cultural and technological transfers across the Tasman. ${ }^{22}$ Clearly, both in terms of British expansion during the nineteenth century and the subsequent development of imperial feeling on the New Zealand periphery, Darwin's notion of the bridgehead is extremely useful: British antipodean civilization was predicated upon an Australasian bridgehead. ${ }^{23}$

The ironies of late nineteenth century New Zealand culture should also be noted here: as Stafford and Williams point out, New Zealand settler culture attempted to distinguish itself from Australia through reference to the "sublimity",24 of the 
country's landscape and the archaic nature of Maori. The arrival of the electromagnetic cable into this cultural milieu provides a powerful symbol for the complex clash of imperialism, modernity and colonial nationalism with a marginalised indigenous culture. Although "born modern", ${ }^{25}$ colonial and latecolonial New Zealand was as far from the industrial and technological centre of empire as it was possible to get, and the colonists were well aware of this. In very real terms, they found themselves on the "periphery of the periphery", ${ }^{26}$ and looked forward to the arrival of the mail boats from Melbourne and later San Francisco with understandable passion.

As could be expected, the colony of New Zealand was in a transitional state in terms of industrial and technological development in 1876. With a European population of only slightly under $400,000^{27}$ and the global depression starting to impact on an already under-developed economy, the commercial viability of the colony looked in doubt. Economic decline had led to the election of Julius Vogel to power in 1873 , on an election platform which promised massive capital expenditure on "the construction of roads, bridges and communications ... and the introduction of settlers . .. ${ }^{28}$ through loans raised on the London financial markets. Vogel himself was something of a colonial visionary, involved in a strong culture of utopianism and futurism $^{29}$ which positioned New Zealand at the centre of a New World Order that would supposedly emerge once the Old World had undermined itself through industrialisation and war. ${ }^{30}$ He had a natural affinity for technological development. In addition to promoting the development of railways, water works, bridges, ports and roads in his 1873 election promise, he eventually brokered the deal for the transTasman cable and became Commissioner of Telegraphs. ${ }^{31}$ 
New Zealand was not a technologically advanced Australasian colony, however. Unlike the centre, where canals, roads, gas lighting, and other industrial infrastructures had been developing since the eighteenth century, the colonists were mainly contending with the brute force and indifference of Nature. Homes were basic and generally self-built, civil infrastructures such as sewage and water rudimentary (if even present in some of the smaller centres, or on the gold-fields where towns had sprung up almost overnight) and travel both time-consuming and dangerous (in the period from 30th June 1875 - 30 $0^{\text {th }}$ June 1877179 people lost their lives at river crossings alone). ${ }^{32}$ Life on the scattered colonial frontier, in timber milling camps, for instance, was even more arduous. Unlike Africa and parts of the United States and South America, New Zealand's rivers were not navigable far inland, and tended to hinder rather than support river transport; milling camps, consequently, were often isolated affairs.

Despite the difficulties, however, civil government and vested interests had developed far enough by the 1860 s to ensure a continuing commitment to commercial and industrial development. Immigration and Public Works were positioned together by the colonial government, ${ }^{33}$ in explicit recognition of their interdependence; the financial success of the colony depended on continued industrialisation, manufacturing and the development of new markets; and industrialisation and manufacturing depended upon attracting skilled migrants. It is important to note that New Zealand governments during this period were concerned to find viable industries for the economy. This would change with the advent of refrigeration in the late $1880 \mathrm{~s}$, but in the context of Vogel’s 1870 proposal for a $£ 10$ million London loan, a global economic downturn, and the need to industrialize as quickly as possible, the problem was pressing. ${ }^{34}$ Reports on Colonial Industry presented to the colonial government in 
1872 present the issue in stark terms: although gold and pastoralism were creating a degree of wealth in the South Island, diversification was called for, and the report identified the Sugar-beet, Fish Curing, Paper Manufacturing, Coal Mines, Sericulture (Mulberry Trees), Timber, Condensed Milk and Weaving industries as economic areas potential migrants should be made aware of..$^{35}$ The same year, in investigating the need to press on with the creation of a colony-wide railway network, several provinces (notably Auckland and Wellington, where labour was particularly scarce) supported a proposal to encourage the immigration of Chinese labourers. ${ }^{36}$ Perhaps aware of the issues faced by the railways in Australia, where the adoption of different gauges in different states had led to serious problems, ${ }^{37}$ the New Zealand government had rejected bids by private companies to build the network, ${ }^{38}$ but then immediately had to grapple with the issue of labour. In this sense, the Australasian bridgehead was involved in a process of industrial experimentation, with New Zealand benefiting from Australian mistakes.

Communication loomed large in these experiments: both within each colony, across the Tasman, and back to the imperial centre. ${ }^{39}$ The Australasian bridgehead in all its commercial, governmental, religious and military guises - was in communication with the imperial centre on all matters of significance, but those communications took months. ${ }^{40}$ The opening of the Suez Canal in 1869 reduced this to a matter of weeks but delays were still common and up to date news was impossible to get until the advent of the telegraph. Moreover, even after the Suez route opened, it was not easily navigable for the sailing ships which carried the vast bulk of Australasian cargo until the late 1890s. Steamships were slower to replace sailing ships on the London - Australasian route than elsewhere, simply because the length of the journey necessitated too much coal. It was only with the widespread 
introduction of the compound or dual expansion steam engine (which used the steam twice over) and the geared steam turbine (later used to turn the ships propellers) that the journey became economic for anything other than high-value cargoes such as mail, which usually necessitated government subsidies. ${ }^{41}$ Given that relationships between New Zealand and Britain were particularly strained during the early 1870 s because of the New Zealand Wars, and some New Zealand politicians were occasionally complaining of "unfair and unkind treatment", ${ }^{42}$ efficient communications with the imperial government were a priority.

From the start, communications between the Australasian bridgehead and the imperial centre were dependent upon government sponsorship. Although commercial interests were heavily involved in proposals for the implementation of telegraph lines, those proposals invariably included a degree of either government subsidy or assurance of monopoly control of the industry, or both. ${ }^{43}$ The reasons for the initial acquiescence to these demands lay at both ends of the system - at Home in London and on the periphery - although the Australasians appear to have been significantly more motivated to make advances. The imperial authorities, while encouraging developments for strategic reasons, were reticent about getting involved in major communications projects after a string of expensive failures with the London - Dover - Calais Cable, the Red Sea Cable and the Atlantic Cable. ${ }^{44}$ Here Darwin's theory of bridgeheads is especially useful: the "diversity of British interests on the periphery" (commercial, governmental, and in Julius Vogel's case, cultural and perhaps even personal) acted to solidify British territorial expansion through (colonial) government subsidised development based on overseas borrowing. ${ }^{45}$ Although gentlemanly capitalists provided some finance, and a great deal of hectoring in the case of the telegraph, the colonial governments carried the financial and commercial risk for 
developments in communications technologies such as railways and the telegraph: ${ }^{46}$ this was free trade on crutches.

As Darwin suggests, however, the Australasian bridgehead functioned as a "hinge or interface between the metropole and a local periphery". ${ }^{47}$ Colonial advances in communications infrastructures were undoubtedly met with pleasure at the centre, where issues of imperial defence were beginning to assume more importance. As the dominant global power, the British Empire had significant strategic issues to deal with, especially in terms of a series of colonial wars and continued tension on the Continent, so that its army and navy were stretched to their limits for much of the late nineteenth century. Technological advance was not always seen in a wholly positive light in this context. One percipient commentator noted in 1852 that

[s]team navigation, railroads and the electrical telegraph . . . have powerfully increased her [Britain's] defensive resources; but at the same time they increase the means of attacking her, and prepare the way that leads to her shores. $^{48}$

The Indian Uprising of 1857 was only one manifestation of strategic problems related to the ratio of indigenous to British troops, supply, and mobilisation. ${ }^{49}$ Once the problems associated with submarine cables were surmounted in the $1860 \mathrm{~s},{ }^{50}$ there was thus a great rush to complete an "All Red Route" 51 around the world, which would touch only on British controlled territory (if at all; the aim was to create an exclusively undersea route) and allow prompt communication with all areas of the empire.

The key to the successful development of an All Red Route was quite simple: each colony (or to use Darwin's category, 'bridgehead') needed to develop an internal network of telegraph lines, which would then be strung together through submarine cables. ${ }^{52}$ Economic needs within each colony would determine the rate at 
which internal telegraph networks were developed, but it was clear by the 1850 s that this was a self-perpetuating process, with eager businessmen and colonial governments pressing forward. Because of the significant advantages held by British firms in both the underlying technology and (perhaps more importantly) the industrial and financial structures required to undertake such a massive project, and because Britain was the only empire with such far-flung colonies in need of strategic integration, Britain would dominate the laying and control of the world telegraphic network. And this is exactly what occurred. By the 1870 s Britain led a powerful submarine cable industry, composed of companies specialising in cable manufacturing, laying and maintenance - and in the case of John Pender's various interests under the umbrella of the Eastern Telegraph Company and its associates, all three. By 1880 Britain controlled 97,658 miles of the world's submarine cables, ${ }^{53}$ and by 1900 over 135,000 miles, amounting to $72 \%$ of all the submarine cables worldwide. ${ }^{54}$ This was not achieved merely to facilitate the cultural integration of centre and periphery, but due to a complex matrix of commercial, governmental, strategic as well as cultural concerns voiced at both the centre and at the periphery.

Strangely, perhaps, there was initially little motivation in New Zealand to connect to the All Red Route (which had reached Singapore by 1871), despite being inundated by offers from cable laying firms since the $1860 \mathrm{~s} .{ }^{55}$ Australia connected to the Singapore line in 1872, in combination with a 2000 mile line from Adelaide to Port Darwin, putting itself in close communication with London as long as the lines remained functional. But New Zealand also benefited from this connection. News that once took weeks to arrive from London now arrived in Melbourne within 12-24 hours, and was immediately put on steamers for the trip across the Tasman to Bluff, where it was relayed across New Zealand's own telegraph system through an 
increasingly sophisticated press system. ${ }^{56}$ In 1874 an alteration to New Zealand's Electric Telegraph Act, 1865, allowed for all telegrams originating in the colonies of New South Wales, Tasmania and Queensland (Victoria had been included years before) to be transmitted across the Tasman by post for no additional charge. ${ }^{57}$ Although the commercial impulse, in tandem with imperial and colonial assurances, got the lines as far as Australia, it took several years to make it the final 1200 miles across the Tasman.

The reasons for this delay were several: submarine cables were no longer viewed as lucrative commercial enterprises, and it was felt (correctly as it turned out) that the trans-Tasman cable would simply not be economic and that the colony had too many other pressing technological concerns. Experience had also shown that up to $50 \%$ or more of telegraphic traffic worldwide was government or commercerelated and the general public tended to avoid the services due to prohibitive costs. Cable laying firms such as Siemens and Eastern Telegraph regularly asked for terms that were unacceptable to the colonial government, such as line monopolies of up to 50 years ${ }^{58}$ and $£ 30,000$ subsidies to ensure profitability. In addition to this, New Zealand was closely involved in negotiations to establish a mail service via San Francisco, ${ }^{59}$ which would provide faster service than via Australia and Suez and would itself be costly. Finally, New Zealand's experience of maintaining a telegraph network indicated it was a problematic and costly business.

The first local telegraph line was developed in Christchurch in 1862, to run alongside the newly laid Christchurch - Lyttelton railway. Samuel Butler was so taken with the contrast between the rugged Canterbury Plains and the new technologies that he began writing philosophical tracts to the Christchurch Press $^{60}$ about machine theory, and later extended this into his chapter in Erewhon which 
explained why machines were banned from this dystopian land. ${ }^{61}$ Butler's satire was an early indication of an antimodern tendency in colonial New Zealand culture, which soon evolved into full archaism, but his faith in the progress of the new technology was somewhat misplaced. The Christchurch line had been built by a private company contracted by the provincial government for the job, mainly for the purposes of enhanced communication between Christchurch and its port at Lyttelton, but it was by no means part of an integrated national strategy. The government received an offer from a Robert Macintyre of Dunedin in June 1863, on behalf of engineers from "Atlantic, Indian and other great telegraph undertakings" to "connect all the provinces in New Zealand together by telegraph wires" and then to connect New Zealand to Australia. But he was rebuffed by a cash-strapped and cynical House of Representatives which was being inundated by similar offers from newly minted telegraph companies offering their services all across the empire. ${ }^{62}$

The following year Julius Vogel began to back the extension of the telegraph system, however, claiming that the extension of the system had the ability to "effect a universal revolution ..." and unite the disparate provinces into one national body. ${ }^{63} \mathrm{~A}$ combination of commercial enterprise and interest from those very provinces had already started the process: the Telegraphic Engineer (based in Christchurch) reported that work on lines was underway across the South Island, in attempts to connect Bluff with Invercargill; Invercargill with Mataura; Mataura with Molyneux; Dunedin with Waitaki; Waitaki with Timaru; and finally Timaru with Christchurch. ${ }^{64}$ The extension of pastoralism in the South Island was undoubtedly fuelling this expenditure by the provincial governments, but it should be viewed as a localised and economically determined phenomenon. In the absence of railways, and with a small and highly dispersed population, the telegraph was believed to be a relatively cheap and effective 
means of communication - especially between the various port towns and their hinterlands. Local communities thus placed ever-increasing amounts of pressure on their ministerial representatives to release funding. ${ }^{65}$ Telegraphic communication (even in the absence of a trans-Tasman cable) meant faster access to prices on the Australian and London markets and could be the difference between success and failure for small farming communities. Despite concerns within central government that telegraphs were "a thing to be avoided in the present financial state of the colony", ${ }^{66}$ and that "the expense would be enormously greater than in England where the poles were placed along the railroad" ${ }^{\prime 67}$ rather than through difficult terrain, there appears to have been considerable interest within provincial governments.

Eric Pawson and Neil C. Quigley have gone further than this, and suggested that New Zealand's telegraph system greatly enhanced communication between the provinces and was implicated in the centralisation of government authority, as Vogel had envisaged ${ }^{68}$ Certainly, when the New Zealand government shifted their proceedings from Auckland to Wellington in 1865, the telegraph system was immediately enhanced. Although the telegraph office remained in Christchurch, the government made it clear to the chief engineer, Alfred Sheath, that it was "anxious"69 to proceed with a Cook Strait cable and ordered soundings for this purpose. Unfortunately for Sheath his subsequent survey was faulty, the landing point for the cable was ill-chosen, and New Zealanders had to put up "with repeated and often lengthy periods when, for one reason or another, it failed to work" ${ }^{70}$ Nevertheless, the relocation of the New Zealand government clearly impacted upon the development of the colony's telegraph network to a far greater degree than either private enterprise or imperial strategy. ${ }^{71}$ The Cook Strait cable was finally landed (after a failed attempt when an accident aboard the cable ship broke the cable) in 
1866 - the same year as the Atlantic Cable. By the late 1860s the colonial government was beginning the process of buying the country's telegraph network off the provinces and extending the network wherever possible, under the direction of the Postmaster General who began issuing regulations to govern the use of the telegraph system. $^{72}$

A combination of pressure from local communities, central government and commercial forces extended the system exponentially over the next decade, with unfortunate results. In 1868 there were 1,183 miles of line with 98,000 messages transmitted; ${ }^{73}$ in 1871 there were 2107 miles of line and 312,874 messages; ${ }^{74} 1874$ 2,530 miles of line and 752, 899 messages; ${ }^{75}$ and 18752986 miles of line and 917,128 messages. ${ }^{76}$ By the early 1870 s most lines began to double the wire carried on them, thus increasing the number of messages that could be sent. Until the 1890s the vast majority of the messages were governmental, but the system was unreliable and prohibitively expensive for most people, with claims that "[i]t really did not carry out the function it was intended to carry out when established, and the expense ... was not in any degree warranted by [its] trifling success ...".77 The Telegraph Department reported frequent complaints throughout 1867 and Sheath was forced to table a 6 page report detailing poor timber quality in the poles used; high cost of labor; absence of good roads; difficulty conveying tools and materials; the return of previously cleared bush; and on several occasions wilful damage of insulators by people opposed to the telegraph system. ${ }^{78}$ Coupled with the problems associated with the Cook Strait cable this did not bode well for Sheath, and he was replaced by Charles Lemon as general manager the following year. Lemon immediately undertook a refit of all the faulty South Island lines. ${ }^{79}$ 
Despite these problems the telegraph system became more than a merely utilitarian tool. It became a symbol of the colony's maturation and development and a marker of New Zealanders' desire for technological development independent of the other Australasian colonies: technological advance was quickly connected to cultural advance. In large part any feelings of pride were articulated within a broader discourse of imperial loyalty, but in fundamental terms this period in New Zealand history witnessed the first growth of a colonial identity distinct from, and sometimes even in opposition to, both imperial and Australasian identity. ${ }^{80}$ Ironically, then, the growth of colonial nationalism went hand in hand with the extension of the electric telegraph system: the settlers sought autochthony wherever they could in order to build a bulwark against the feelings of isolation they felt (exacerbated by the wars). That could be found in either archaism or the futurism implicit in technological advance. By the time Julius Vogel was appointed as Telegraph Commissioner in 1869 it was abundantly clear that the network was viewed as something of considerable importance to the colony as a whole. He refused a request in the House for telegraph offices to be closed on Sundays, ${ }^{81}$ on the grounds that "the disturbed state of the country" ${ }^{82}$ required important telegrams to be despatched without a moment's delay.

In 1870 Vogel began to move drafts of the Immigration and Public Works Act, and involve himself with the issue of "telegraphic communication with Europe" ${ }^{83}$ As Commissioner for Telegraphs he felt that the colonies should act jointly and not allow any future imperial or world network to fall into commercial hands, voicing a clear preference for an imperial network that would be quite distinct from any wider world network that might compromise imperial security in times of war as well as peace. ${ }^{84}$ Vogel was eventually charged with the important task, in this context at least, of securing a reasonable contract for the laying of the trans-Tasman 
cable and the completion of an imperial network that spanned the world. Impetus did not come from the imperial government, who were quite content with having established communication with Australasia generally. Indeed, Vogel faced considerable difficulty convincing the British to ignore their own economic difficulties and finance his public works and communications plans, despite an obviously strong desire throughout the empire for the development of 'better Britains'. The general feeling was summed up well by a contributor to Blackwood's Edinburgh Magazine in 1862:

In these outlying unpeopled regions of the globe the British race increases with a rapidity beyond the reach of the Continental nations; and every year is bringing closer the scattered sections of our numerous and powerful race, annihilating distances by the ever-increasing triumphs of the railway, telegraph and steam navigation. New Zealand, Australia, the Cape - in fact all our colonies, by the force of blood and the necessity of position, will ere long become important maritime Powers. ${ }^{85}$

New Zealand's industrialization, represented in this case by the growing telegraph system, was therefore symbolic of not only colonial nationalist, but imperial sentiment. Politicians on the periphery engaged in what could be termed 'imperial boosterism' at the same time as they furthered their colony's own interests. Rather than (necessarily) being an obsequious process of recolonisation as Belich argues, ${ }^{86}$ it was often a potentially arrogant assertion of futurism, wherein the colonies would strengthen the centre against both external enemies and the internal pressures exerted by industrial modernity. Miles Fairburn and Lyman Tower Sargent have pointed out the arcadian component to this sequence of events, ${ }^{87}$ but it is equally valid to posit a futurist, technological component as expressed by Vogel and others. In a burst of technological hubris, for instance, one MP suggested in 1876 that the telegraph be used for voting, in an early manifestation of the desire for New Zealand to become a 
'social laboratory' ${ }^{88}$ As Stafford and Williams suggest, "[t]he contradiction at the heart of Maoriland is that its archaism cohabits with and compensates for the colony's sense of its own modernity". ${ }^{89}$

Vogel had been pressing for a trans-Tasman cable since the All Red Route reached Bombay in 1870, but commercial conditions were not right and other New Zealand politicians were wary of further expenditure on telegraphs. ${ }^{90}$ Worse still, while Vogel was in London in 1871, it became clear that there was "no prospect at all of the British government supporting the cable". ${ }^{91}$ Over the next 5 years, Vogel approached companies and tried to broker a deal for a trans-Tasman cable, amidst complaints in parliament back in New Zealand regarding his mounting costs and the point of having a Premier who was often absent from the country for long periods. To Vogel the point was clear: he needed to raise a substantial loan and connect New Zealand into the imperial telegraph network, for the benefit of both the colony and the empire. The subject was discussed at length at the inter-colonial conference in Sydney during 1873, where it was decided that telegraphic communication between the various colonies of the empire was of the utmost importance to defence and internal relations between colonies. Vogel's vision for the empire dovetailed with a resurgence in calls for imperial federation, which were gathering pace over the later third of the nineteenth century. The telegraph system, and technological advance generally, undoubtedly informed the debate. As Duncan Bell notes, "[t]he second half of the nineteenth century was infused by a commanding belief in the power of science and technology to solve the manifold problems of society", ${ }^{92}$ and ideas about imperial federation reflected a "fundamental shift in the manner in which people viewed the world and their relationship to it". ${ }^{93}$ 
Vogel eventually agreed to a proposal by a Tasmanian politician by the name of Audley Coote, on behalf of the British firm Siemens Brothers, to lay cables between New Zealand, New South Wales, Queensland and Singapore. The plan was bold, in that rather than merely linking New Zealand to Australia, it would create a completely new second line back to Britain, securing more reliable communications (the Australia - Java line was perpetually in need of repair due to the tropical heat and most news still arrived by steamer) and dividing the cost between all the Australasian colonies. The idea was ratified by the New Zealand parliament but the NSW parliament was slow to follow suit. After two years of negotiations the deal fell through and the New Zealanders had to look elsewhere, eventually accepting a proposal by John Pender's Eastern Extension Australasia and China Telegraph Company, which already ran the Singapore cable and was an associate of the dominant international line company. ${ }^{94}$ The final proposal called for a $£ 7500$ government subsidy per year for 10 years for the trans-Tasman cable for a cost of $£ 6$ / 15/- for a cable from New Zealand to London. The resultant cable would only be economic to this extent because of an existing $£ 20,000$ subsidy from New Zealand and the Australian colonies for the London - Darwin section of the line. Companies were simply not willing to shoulder all of the commercial risk entailed in these projects. ${ }^{95}$ This contract was signed on 24 June 1875 , with an assurance that the line would be operational no later than 30 April the following year. ${ }^{96}$

Contrary to the debacles associated with the development of the internal network, the project ran smoothly, over-seen by the London engineering firm Clark, Forde \& Co. ${ }^{97}$ A 1200 mile cable was laid in four pieces by the specialist cable-laying ships the Hibernia and the Edinburgh, making landfall on February $17 .^{98}$ The name "Cable Bay" replaced "Schroeder's Mistake" (the original name of the bay, at the top 
of the South Island) a week later. ${ }^{99}$ Despite being overshadowed by the abolition of the provinces the same year and (ironically) Julius Vogel's return from London to a state banquet in Wellington, ${ }^{100}$ the trans-Tasman cable received considerable newspaper space, both in the lead up to the connection and during the rather extensive celebrations in Nelson, which included a picnic organised by the officers of the Hibernia, a Masonic Lodge banquet, a special sermon at the Anglican Cathedral, and a rail journey to the Waimea Steeplechase. ${ }^{101}$ In a passage which neatly captures the sense of futurism which (ironically) cohabited with archaism in New Zealand, The North Otago Times noted that:

Wonderful as the modern triumphs of Science have been, most prominent among them all is the chaining of the lightning to the car of the world's progress, converting, almost without metaphor it may be said, the very thunderbolts of Jove into pens of ready writers. ${ }^{102}$

Despite the public hyperbole, however, the exorbitant cost of telegrams from New Zealand to Britain raises an obvious point: most telegrams only went as far as Australia, and even then the bulk of them were of a governmental or commercial nature. On the Monday following the initial connection only 54 inward cables were received and 93 sent, and the cable was never a commercial success. Over the course of the first year 3467 cables were sent from Australia to New Zealand through the cable and 3268 from New Zealand to Australia. The same year there was a break in all three of the Cook Strait cables, ${ }^{103}$ and telegraphic communication was proving so intermittent that negotiations began for a second cable to ensure "uninterrupted communication with the rest of the world". ${ }^{104}$ With the cost of line maintenance increasing yearly, and absolutely no support from the British government or commercial interests, nothing further was achieved until the laying of the Pacific Cable in 1902. Uptake of the technology by the general public was slow due to the 
high cost of telegrams and the increasing efficiency of the mail services. Efficiency did increase, to the point where 23 telegrams were sent for every 100 letters, ${ }^{105}$ and New Zealanders became the highest users of telegraphic services anywhere in the world per capita, ${ }^{106}$ but most of the users remained either governmental or commercial and maintenance costs were an ongoing issue.

Major gains were made because of the telegraph, however, especially in relation to the development of New Zealand culture and identity. Two rather telling breakthroughs were the introduction of New Zealand Standard Time in $1868^{107}$ and the accurate calculation of longitude in $1876 .{ }^{108}$ In this sense, as Quigley and Pawson suggest, the telegraph system was involved in not only the "shrinking and homogenising" ${ }^{109}$ of colonial New Zealand culture, but in the ongoing mapping of the country identified as so important by Giselle Byrnes. ${ }^{110}$ Direct connection to Britain at the governmental level undoubtedly assisted the country to assert its imperial credentials when opportunities arose as well (the most famous perhaps being Premier Seddon's promise of troops for the South African War before war had even been declared), but the development of the press system was probably the most significant feature. ${ }^{111}$ As Simon Potter points out, New Zealand and Australia were tied into an imperial system of news distribution almost solely because the ownership of the lines. ${ }^{112}$ The "Eastern and Eastern Extension Telegraph Company enjoyed a monopoly over Australian traffic", ${ }^{113}$ and New Zealand remained almost totally dependent upon an Australasian model of news distribution for the rest of the nineteenth century. ${ }^{114}$ In this sense, the Australasian bridgehead was perpetuated by the imperial cable network not only at a commercial, but a cultural level.

The extension of the imperial cable network to nineteenth century New Zealand was by no means a great triumph of engineering, therefore, but it was 
nevertheless a triumph for the empire. The fact that the system was extended across the Tasman from Australia despite a lack of commercial merit, a lack of public interest, and for many years outright hostility from both the imperial and colonial governments, speaks volumes to the merely discursive, or perhaps imaginative, power exerted by the idea of empire - and the interpenetration of this conceit with both technological modernity and utopianism. The project is reflective of Miles Taylor's identification of an "imperialist euphoria" $" 115$ which took hold during the last third of the nineteenth century, and interestingly suggests that this euphoria may have been enough in itself (especially when attached to the mind of a man like Julius Vogel) to force progress against commercial logic. Once established in New Zealand, for reasons nationalist as well as imperial, the telegraph system came to symbolise the ultimate connection between the past and present, in a mode of colonial nationalism which claimed autochthony through both archaism and technological modernity.

\section{Notes}

1 'The Submarine Telegraph', Blackwood's Edinburgh Magazine, Vol. 70 (433) Nov 1851, p.562.

${ }^{2}$ North Otago Times, Saturday, February 19, 1876, p.2.

${ }^{3}$ Parsons, The Story of New Zealand, 418-419.

${ }^{4}$ Manuel, 'Telegraph Wires: "The Nerves of the Earth."' Notes and Queries, VI (1870), 173.

${ }^{5}$ Otis, 'The Metaphoric Circuit', 105-128.

6 'Our National Defences', Blackwood's Edinburgh Magazine Vol. 72 (441) Jul 1852, p.1; Headrick, The Invisible Weapon.

${ }^{7}$ Taylor, 'John Bull and the Iconography of Public Opinion in England', 95.

${ }^{8}$ Marsden and Smith, Engineering Empires; Ferguson, Empire; Headrick, The Tentacles of Progress; Headrick, The Tools of Empire.

${ }^{9}$ Kubicek, Review of Ben Marsden and Crosbie Smith, Engineering Empires, 289.

${ }^{10}$ Pocock, The Discovery of Islands.

${ }^{11}$ Gallagher and Robinson, 'The Imperialism of Free Trade, 1815-1914'.

${ }^{12}$ Cain and Hopkins, 'Gentlemanly Capitalism and British Imperialism: The Old Colonial System'.

${ }^{13}$ Hall, Civilising Subjects; Thompson, The Empire Strikes Back; Ballantyne, 'Race and the Webs of Empire.

${ }^{14}$ Shils, 'Centre and Periphery'.

${ }^{15}$ Porter, The Absent-Minded Imperialists.

${ }^{16}$ For example: Sartori, 'Review Article: The British Empire and Its Liberal Mission'; Jones, 'Review of Andrew Thompson, The Empire Strikes Back?; Hall, 'Review of Wendy Webster, Englishness and Empire 1939-1965; Pomper, 'The History and Theory of Empires'; Daunton, 'Britain's Imperial Economy: Review Of "The Oxford History of the British Empire".

${ }^{17}$ Darwin, 'Imperialism and the Victorians: The Dynamics of Territorial Expansion'. 
${ }^{18}$ Darwin, 'Imperialism and the Victorians'. p.629.

${ }^{19}$ For example: Pember Reeves, State Experiments; Sinclair, A History of New Zealand; Sinclair, ed., Tasman Relations.

${ }^{20}$ Mein Smith, 'Remoter Australasia 1861-1890'; Mein Smith, 'The Ties that Bind'; Mein Smith, 'New Zealand Federation Commissioners'; Mein Smith and Hempenstall, 'Australia and New Zealand'; Hempenstall, Mein Smith and Goldfinch, 'Anzac Neighbours'.

${ }^{21}$ Belich, Making Peoples; Belich, Paradise Reforged.

${ }^{22}$ Miles Fairburn argues persuasively for the impact of America as well in later years. See Fairburn. 'Is There a Good Case for New Zealand Exceptionalism?'.

${ }^{23}$ Peter Beilharz provides a useful summation of antipodean culture in 'The Antipodes'. See also

Pocock, 'The Antipodean Perception'.

${ }^{24}$ Stafford and Williams, Maoriland, p.11.

${ }^{25}$ Brown, 'Born Modern: Antipodean Variations on a Theme'.

${ }^{26}$ Herrera, 'Review of Eric Hineraker and Peter C. Mancall, At the Edge of Empire.

${ }^{27}$ Statistics of the Colony of New Zealand for the Year 1876 (Wellington, 1876), p.13.

28 'Correspondence Relative to the New Zealand (Roads Etc) Loan Act', AJHR, Vol.I, 1870, A-9c.

${ }^{29}$ Sargent and Sargisson, Living in Utopia; Sargent, New Zealand Utopian Literature: An Annotated Bibliography.

${ }^{30}$ Vogel, Anno Domini 2000.

${ }^{31}$ Dalziel, Julius Vogel, $141 \mathrm{ff}$.

32 'Persons Drowned in New Zealand Rivers', AJHR, Vol.II, 1877, H-42.

${ }^{33}$ The most obvious evidence of this was the 'Immigration and Public Works Act' (1870).

${ }^{34}$ This issue was not as marked in Australia, where the economy was developed enough as early as the 1840 s to include significant service sectors in the major cities. See Butlin, Forming a Colonial Economy, 155.

35 'Joint Committee on Colonial Industries', AJHR, Vol.III, 1872, G-16.

36 'The Introduction of Chinese Labour into New Zealand', AJHR, Vol.II, 1872, D-12.

${ }^{37}$ Blainey, The Tyranny of Distance, 248-250.

38 'Correspondence with Mr. Brogden Relative to the Formation of a Company for Construction of Railways in New Zealand', $A J H R$, Vol.II, 1872, D-14.

${ }^{39}$ In his classic account of Australian economic history, Noel Butlin suggests that "throughout almost all of the 40 years after 1860 , the construction of new assets in communications accounted for $75-80 \%$ of all government new capital formation". See Butlin, Investment in Australian Economic

Development, 291.

${ }^{40}$ Problems of communication between New Zealand and London were highlighted by the 'Granville affair' of 1869-1870, where relationships between the imperial and colonial governments became significantly strained over military contributions to the New Zealand wars. See 'Conduct of the Imperial Government', in NZPD, 13 July 1870.

${ }^{41}$ Blainey, The Tyranny of Distance, 270-271.

${ }^{42} \mathrm{Mr}$. Gray, 'Conduct of the Imperial Government', NZPD 13 July 1870, 362.

43 'Papers Relating to the Establishment of Telegraphic Communication Between England the Australian Colonies', AJHR, 1863, D-3; 'Report of the Submarine Electric Telegraph Committee', AJHR, Vol.III, 1872, H-5.

${ }^{44}$ Airey, The Taming of Distance, 28.

${ }^{45}$ Hawke, The Making of New Zealand, 68; Lloyd- Prichard, An Economic History of New Zealand, 118-119.

${ }^{46}$ Butlin, Investment in Australian Economic Development, 291-292.

${ }^{47}$ Darwin, 'Imperialism and the Victorians'. 629.

48 'Our National Defences', Blackwood's Edinburgh Magazine, 72 (1852), 21.

${ }^{49}$ Nasson, Britannia's Empire, 122.

${ }^{50}$ Headrick, The Tools of Empire, 159.

${ }^{51}$ Kennedy, 'Imperial Cable Communications and Strategy, 733.

${ }^{52}$ In most cases these ran alongside railway lines, but in New Zealand they frequently outran them, because in the absence of governmental support for a railway, a telegraph line appeared as a relatively cheap alternative.

${ }^{53}$ Ferguson, Empire, 70.

${ }^{54}$ Headrick, Tools of Empire, p.162.

${ }_{55}$ Airey, The Taming of Distance, p.4.

${ }^{56}$ Day, The Making of the New Zealand Press. 
${ }_{58}^{57}$ New Zealand Gazette, June 18, 1874, p.118.

${ }^{58} \mathrm{Mr}$. Henley to Mr. J. Morrison, 'Correspondence Relating to Proposed Submarine Electric Cable between Australia and New Zealand', AJHR, Vol.II, 1870, E-6.

59 'Papers Relative to the San Francisco Mail Service', $A J H R$, Vol.II, 1870, E-4.

${ }^{60} \mathrm{~S}$. Butler, 'Darwin Among the Machines', The Press, June 13, 1863.

${ }^{61}$ Butler, Erewhon, 189-219.

62 'Papers Relating to the Establishment of Telegraphic Communication', AJHR, 1863, D-3.

${ }^{63}$ Mr. Vogel, 'Telegraphic Communication', NZPD, 24 Nov. - 13 Dec. 1864, p.69.

${ }^{64}$ 'Report of the Telegraphic Engineer', $A J H R, 1864, \mathrm{D}-1 \mathrm{c}$.

${ }^{65}$ For example: NZPD, 09 July - 29 August, 1867, 857 (Wellington - Wanganui); NZPD, 25 August 24 Sept., 1868, 857 (Onehunga - Manukau Heads; Mercer - Thames Goldfield); NZPD, 20 July - 03 Sept., 1869, 394 (Lyttelton - Akaroa) ; NZPD, 14 June - 20 July, 1870, 51 (Extension Nth of Auckland); 69 (Lyttelton - Adderley Head); 68 (Horonui - Waiau); 51 (Manukau Pilot Station); 189 (Invercargill to Winton); 22 (Patea - New Plymouth); 201 (Taupo).

${ }^{66} \mathrm{Mr}$. Stafford, NZPD, 26 July -30 Oct., $1865,249$.

${ }^{67} \mathrm{Mr}$. Fitzgerald, $N Z P D, 26$ July -30 Oct., 1865, 249.

${ }^{68}$ Pawson and Quigley, 'The Circulation of Information and Frontier Development', 65-76.

${ }^{69} \mathrm{~W}$. Gisborne (Under-Secretary) to Alfred Sheath, 10 June, 1865, AJHR, 1865, D-1d.

${ }^{70}$ Airey, The Taming of Distance, 5.

${ }^{71}$ Indeed, given that the provinces were abolished the same year the trans-Tasman cable was laid in 1876 , there is good reason to posit a rather tight interdependence between the extension of the telegraph system and the extension of government centralisation, in terms of enhanced communication on the one hand, and a ready market for high volumes of telegrams on the other.

72 'Regulations and Conditions Under Which Telegrams May Be Transmitted on the Line of Electric Telegraph Belonging to the General Government of New Zealand', AJHR, 1865, D-1e; See also: New Zealand Gazette, June 8, 1870, 254-255; August 31, 1872, 674; February 20, 1873, 118; June 18, 1874, 391; May 25, 1877, 573.

73 'Annual Report of the New Zealand Telegraph Department', AJHR, 1868, E-5.

74 'Annual Report of the New Zealand Telegraph Department', AJHR, Vol.II, 1871, E-2.

75 'New Zealand Telegraph Department (Tenth Annual Report)', AJHR, Vol.II, 1874, F-1a.

${ }^{76}$ 'New Zealand Telegraph Department (Eleventh Annual Report)'AJHR, Vol.II, 1875, F-1a.

${ }^{77}$ Mr. Travers, NZPD, Vol.I Pt.I, 9 July - 21 August, 1867, 178.

78 'Third Annual Report on the Working and Progress of the New Zealand Telegraph Department', AJHR, 1867, E-5.

${ }^{79}$ 'Fourth Annual Report on the Working and Progress of the New Zealand Telegraph Department' $A J H R, 1868$, E-5.

${ }^{80}$ Gibbons, 'Cultural Colonization and National Identity', 5-17; Hilliard, 'Colonial Culture and the Province of Cultural History', 82-97; Sinclair, 'New Zealanders and Britons', 192-211.

${ }^{81}$ Mr. Burns, NZPD, 20 July - 03 Sept. 1869, 755.

${ }^{82} \mathrm{Mr}$. Vogel, NZPD, 20 July - 03 Sept. 1869, 755.

${ }^{83}$ 'Correspondence Relative to the New Zealand (Roads Etc) Loan Act', AJHR, Vol.I, 1870, A-9c. ${ }^{84}$ Ibid.

${ }^{85}$ Blackwood's Edinburgh Magazine, 92 (December 1862), 712.

${ }^{86}$ Belich, Paradise Reforged, 54-68.

${ }^{87}$ Fairburn, The Ideal Society and Its Enemies; Tower Sargent, New Zealand Utopian Literature.

${ }^{88} \mathrm{Mr}$. Waterhouse, NZPD, Vol. 20, 15 June - July 28 1876, 469-470.

${ }^{89}$ Stafford and Williams, Maoriland, 11.

${ }^{90}$ Dalziel, Julius Vogel, 141-143.

${ }^{91}$ Dalziel, Julius Vogel, 142.

${ }_{92}$ Bell, 'Dissolving Distance: Technology, Space, and Empire in British Political Thought', 549.

${ }^{93}$ Bell, 'Dissolving Distance', 561.

${ }^{94}$ Dalziel, Julius Vogel, 143.

${ }^{95}$ Airey, The Taming of Distance, 44.

${ }^{96}$ Mr. Reynolds, NZPD, Vol.19, 28 Sept. -21 Oct. 1875, 528.

${ }^{97}$ Airey, The Taming of Distance, 5-6.

98 'New Zealand Telegraph Department (Twelfth Annual Report)', AJHR, Vol.II, 1876, F-1a; The Star, Friday, February 18, 1876.

${ }^{99}$ Airey, The Taming of Distance, 16. 
${ }^{100}$ The Taranaki Herald, Saturday, February 19, 1876; The Evening Herald, Friday February 18, 1876; The Timaru Herald, Saturday February 19, 1876; The Daily Southern Cross, Friday February 18, 1876.

${ }^{101}$ Airey, The Taming of Distance, 16.

${ }^{102}$ North Otago Times, Saturday, February 19, 1876, 2.

103 'New Zealand Telegraph Department (Twelfth Annual Report)', AJHR, Vol.II, 1876, F-1a.

104 'Papers Relative to the San Francisco Mail Service', AJHR, Vol.II, 1876, F-3.

105 'New Zealand Telegraph Department (Twelfth Annual Report)', AJHR, Vol.II, 1876, F-1a.

${ }^{106}$ Parsons, The Story of New Zealand, 418-419.

${ }^{107}$ Belich, Making Peoples, 442.

108 'Telegraphic Distances of Longitude', AJHR, Vol.II, 1876, H-6.

${ }^{109}$ Belich, Making Peoples, 443.

${ }^{110}$ Byrnes, Boundary Markers.

${ }^{111}$ Day, The Making of the New Zealand Press, 99-100.

${ }^{112}$ Potter, News and the British World: The Emergence of an Imperial Press System, 1.

${ }^{113}$ Potter, 'Communication and Integration', 195.

${ }^{114}$ Potter, News and the British World, 33.

${ }^{115}$ Taylor, 'John Bull and the Iconography of Public Opinion in England', 95. 